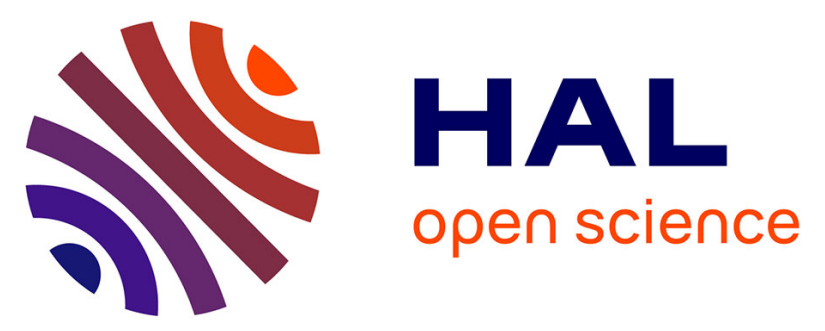

\title{
Fabrication of Robust Spatially-Resolved Photochromic Patterns on Cellulose Papers by Covalent Printing for Anti-Counterfeiting Applications
}

Guillaume Bretel, Erwan Le Grognec, Denis Jacquemin, Takashi Hirose, Kenji Matsuda, Francois-Xavier Felpin

\section{- To cite this version:}

Guillaume Bretel, Erwan Le Grognec, Denis Jacquemin, Takashi Hirose, Kenji Matsuda, et al.. Fabrication of Robust Spatially-Resolved Photochromic Patterns on Cellulose Papers by Covalent Printing for Anti-Counterfeiting Applications. ACS Applied Polymer Materials, 2019, 1 (5), pp.1240-1250. 10.1021/acsapm.9b00266 . hal-03016826

\section{HAL Id: hal-03016826 https://hal.science/hal-03016826}

Submitted on 20 Nov 2020

HAL is a multi-disciplinary open access archive for the deposit and dissemination of scientific research documents, whether they are published or not. The documents may come from teaching and research institutions in France or abroad, or from public or private research centers.
L'archive ouverte pluridisciplinaire HAL, est destinée au dépôt et à la diffusion de documents scientifiques de niveau recherche, publiés ou non, émanant des établissements d'enseignement et de recherche français ou étrangers, des laboratoires publics ou privés. 


\section{Fabrication of Robust Spatially-Resolved Photochromic Patterns on Cellulose Papers by Covalent Printing for Anti-Counterfeiting Applications}

Guillaume Bretel, ${ }^{\star}$ Erwan Le Grognec, ${ }^{\dagger}$ Denis Jacquemin,${ }^{\dagger}$ Takashi Hirose,${ }^{\dagger}$ Kenji Matsuda,${ }^{\dagger}$ François-Xavier Felpin**

†Université de Nantes, CNRS UMR 6230, CEISAM, F-44000 Nantes, France

$\dagger$ Department of Synthetic Chemistry and Biological Chemistry, Graduate School of Engineering, Kyoto University, Katsura, Nishikyo-ku, Kyoto 615-8510, Japan

E-mail: fx.felpin@univ-nantes.fr

aBSTRACT GRAPHIC
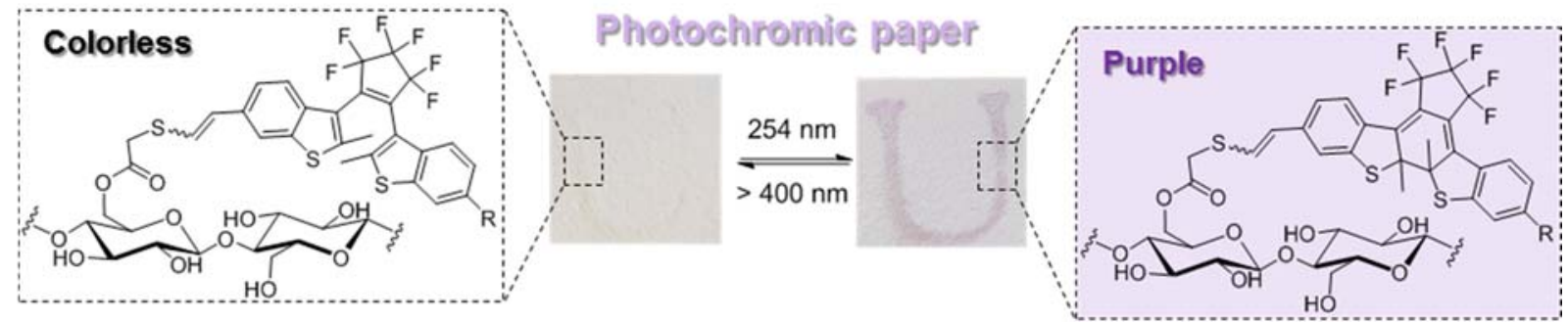

\section{aBSTRACT}

Despite its millennial age, cellulose paper remains the preferred material for domestic and professional printings, covering applications from simple office paperwork to fiducial solutions such as bills, passports, and head letters. The creation of robust photochromic patterns on cellulose papers for anti-counterfeiting applications is an important and still partially unaddressed challenge. In this contribution, we report the covalent printing of dibenzothienylethenes as photochromic compounds through a spatially-controlled light mediated thiol-X ligations. Photophysical and theoretical studies provide evidences for a reversible photochromism behavior, not affected significantly by the polar environment of the cellulose matrix, and demonstrates a high fatigue resistance over 18 successive write-erase cycles. The strong coloration-discoloration switch can be easily followed by a direct nakedeye readout. 


\section{G KEYWORDS}

Cellulose paper; Photochromic pattern; Thiol-yne reaction; Covalent printing; Dibenzothienylethene, Photoswitch

\section{口 INTRODUCTION}

While electronic devices flood our everyday life, paper prints paradoxically remain a modern media of communication and storage in both domestic and professional usages. Indeed, despite its millennial age, cellulose paper is more than ever a modern material as its low cost, disposability, stability, recyclability, and biocompatibility, are all major benefits in the development of sustainable societies.

The fabrication of functional papers, expanding the traditional usages of cellulose paper, is a particularly active field of research with promising applications in area as diverse as medicine, ${ }^{1-4}$ catalysis, ${ }^{5-9}$ analytical, ${ }^{10-13}$ and environmental sciences. ${ }^{14-16}$ In this framework, the incorporation of photochromic dyes within the cellulose matrix allows the fabrication of photochromic papers as potential anti-counterfeiting devices or rewritable materials. ${ }^{17}$ Creating photochromic patterns on cellulose papers for anti-counterfeiting applications is an ambitious objective needing important requirements: $(i)$ a spatial control of the cellulose functionalization; (ii) a reversible photochromism, not affected by the cellulose matrix; (iii) a robust patterning, insensitive to washing processes; and (iv) a good contrast for a naked-eye readout.

The vast majority of published works reports the preparation of photochromic papers using merocyanine dyes as photoactive compounds without any spatial control of the cellulose functionalization, excluding any molecularly imprinted patterns. ${ }^{18-25}$ Moreover, when covalently anchored to the material surface, the photochromism of merocyanine dyes is frequently affected by the polar environment of the cellulose matrix as the colored open form is strongly stabilized within the hydrogen bond network of cellulose. ${ }^{19-20}$ The irreversibility of the photochromism can be prevented through the impregnation of merocyanine dyes with a polymer carrier within the cellulose matrix, ${ }^{18,22,26}$ but the creation of photochromic patterns through a spatial control of the functionalization is still not demonstrated through these studies.

Diarylethenes are well-known photochromic compounds, derived from stilbene, which exist under a poorly conjugated open-form, absorbing in the UV region, and a strongly conjugated closed-form presenting a red-shifted absorption, typically in the 500-600 nm 
domain. ${ }^{27-28}$ Upon UV-light irradiation the open-ring isomer undergoes a $6 \pi$ electrocyclization to furnish the closed-ring isomer which can be back converted upon exposure to visible light. Most diarylethenes are thermally irreversible (P-type) compounds, although, thermally unstable (T-type) diarylethenes have been reported as well. ${ }^{28}$ Koga et al. prepared a remarkable photochromic paper by impregnation of cellulose fibers with a solution of diarylethenes in ionic liquids. ${ }^{29}$ The absence of charges in both the open- and closed-ring isomers prevents the polar environment of cellulose to excessively stabilize one form with respect to the other and induce an unwanted irreversible photochromism behavior. Again, such strategy excludes any creation of photochromic patterns as paper fibers are all impregnated with the photochromic solution and physisorbed dyes could suffer from a limited stability as they are susceptible to be washed off from the material upon contact with liquids. ${ }^{30}$

Therefore, robust photochromic papers remain to be developed through an original strategy allowing a spatial control of the cellulose functionalization. In this work, we report the first strategy allowing the creation of robust photochromic patterns on cellulose paper through our concept of covalent printing, ${ }^{31-32}$ which employs spatially-controlled thiol-X ligations. Our strategy exploits the photophysical properties of dibenzothienylethenes (DBE) ${ }^{33}$ and features: (i) an efficient and fast coloration-discoloration process upon appropriate light irradiation; (ii) a thermal stability of the DBE isomers as shown by both theory and experiment; (iii) a good color contrast; and (iv) a high fatigue resistance, allowing many cycles to be performed without significant loss of performances.

\section{- EXPERIMENTAL SECTION}

General remarks. All commercial solvents and reagents were used as received from SigmaAldrich, Fischer Scientific Ltd or Alfa Aesar. Whatman grade 6 filter paper was used as the cellulose source. ${ }^{1} \mathrm{H}$ and ${ }^{13} \mathrm{C}$ NMR spectra were recorded at 300 or $400 \mathrm{MHz}$ and 75 or 100 $\mathrm{MHz}$, respectively. Proton chemical shifts were internally referenced to the residual proton resonance in $\mathrm{CDCl}_{3}(7.26 \mathrm{ppm})$. Carbon chemical shifts were internally referenced to the deuterated solvent signals in $\mathrm{CDCl}_{3}(77.16 \mathrm{ppm})$. Melting points were recorded on a Stuart Scientific 7SMP3 apparatus. FT-IR spectra were recorded on a Bruker Tensor 27 spectrometer by the ATR technique. HRMS spectra were recorded on a Xevo G2-XS Qtof. UV-visible absorption spectra were recorded using a Shimadzu UV-2501 PC 
spectrophotometer for all compounds before the grafting onto cellulose and a Perkin Elmer lambda 1050 was used for the study of papers.

General procedure for the pre-treatment of cellulose filters. A piece of paper (ca. 140 $\mathrm{mg}$ ) was immersed in an aqueous solution of $\mathrm{NaOH}(40 \mathrm{~mL}, 10 \mathrm{wt} \%)$ and the mixture was shaken for $24 \mathrm{~h}$ on an orbital agitator. The paper was washed 6 times with $\mathrm{EtOH}$ and stored in EtOH.

Synthesis of dithiodiglycolic acid. A round-bottom flask was charged with $1 \% \mathrm{H}_{2} \mathrm{O}_{2}$ aqueous solution $(120 \mathrm{~mL})$, tetrabutylammonium iodide $(200 \mathrm{mg}, 0.54 \mathrm{mmol})$ and thioglycolic acid $(5 \mathrm{~g}, 54.3 \mathrm{mmol})$. The resulting mixture was stirred for $1 \mathrm{~h}$. The crude product was extracted with ethyl acetate $(3 \times 50 \mathrm{~mL})$. The combined organic layers were washed with water $(5 \times 40 \mathrm{~mL})$, dried with $\mathrm{MgSO}_{4}$ and concentrated under vacuum to give the corresponding product as a red powder $(9.88 \mathrm{~g}, 99 \%)$ which was used without further purification.

Grafting of dithiodiglycolic acid onto cellulose paper. A pre-treated cellulose paper was washed 3 times with anhydrous toluene and placed in a flame-dried round-bottom flask under argon with dry toluene $(20 \mathrm{~mL})$. A solution of $\mathrm{BF}_{3} . \mathrm{Et}_{2} \mathrm{O}$ in toluene $(1 \%$ in $1.1 \mathrm{~mL})$ and dithiodiglycolic acid (471.9 $\mathrm{mg}, 2.59 \mathrm{mmol})$ was added to the reaction mixture. The resulting solution was stirred for $24 \mathrm{~h}$ at $110^{\circ} \mathrm{C}$ on an orbital agitator, protected from light and under argon. Then, the paper was washed successively with $\mathrm{EtOH}, \mathrm{MeOH}$, acetone and $\mathrm{CH}_{2} \mathrm{Cl}_{2}$, dried under vacuum and stored under argon.

2-Methylbenzothiophene (1). A four necked flask was charged with benzothiophene (5 g, $37.26 \mathrm{mmol})$ in dry THF $(40 \mathrm{~mL})$ and cooled to $-78^{\circ} \mathrm{C} . n$-BuLi $(25.6 \mathrm{~mL}, 40.99 \mathrm{mmol}, 1.6$ $\mathrm{M}$ in hexane) was added slowly and the mixture was stirred for $1 \mathrm{~h}$. Then, methyl iodine (2.6 $\mathrm{mL}, 40.99 \mathrm{mmol}$ ) was added and the solution was stirred for 40 minutes at $-78{ }^{\circ} \mathrm{C}$. The resulting mixture was quenched with cold water $(100 \mathrm{~mL})$, extracted with ether $(2 \times 50 \mathrm{~mL})$, washed with brine $(100 \mathrm{~mL})$ and concentrated to give 1 as a white powder $(5.46 \mathrm{~g}, 99 \%)$. mp 50-51 ${ }^{\circ} \mathrm{C}$ [ Lit. $\left.^{34} 51-52{ }^{\circ} \mathrm{C}\right]$. IR (ATR) v 1430, 1196, 1134, 1016, 865, 828, 743, 721, 562, $488 \mathrm{~cm}^{-1} .{ }^{1} \mathrm{H}$ NMR $\left(\mathrm{CDCl}_{3}, 400 \mathrm{MHz}\right) \delta 7.76(\mathrm{~d}, 1 \mathrm{H}, J=7.9 \mathrm{~Hz}), 7.66(\mathrm{~d}, 1 \mathrm{H}, J=7.4 \mathrm{~Hz})$, 7.34-7.23 (m, 2H), 6.98 (s, 1H), $2.60(\mathrm{~s}, 3 \mathrm{H}) .{ }^{13} \mathrm{C} \mathrm{NMR}\left(\mathrm{CDCl}_{3}, 100 \mathrm{MHz}\right) \delta 141.0,140.6$, $139.9,124.2,123.5,122.7,122.1,121.7,16.3$. HRMS $\left(\mathrm{ASAP}^{+}\right) \mathrm{m} / z[\mathrm{M}+\mathrm{H}]^{+}$Calcd for $\mathrm{C}_{9} \mathrm{H}_{9} \mathrm{~S}$ 149.0425; Found 149.0427.

3-Bromo-2-methylbenzothiophene. In a round-bottom flask, a solution of 2methylbenzothiophene $(5.45 \mathrm{~g}, 36.82 \mathrm{mmol})$ in $\mathrm{AcOH} / \mathrm{CHCl}_{3}(1 / 1,100 \mathrm{~mL})$ was stirred with 
N-bromosuccinimide $(7.21 \mathrm{~g}, 40.49 \mathrm{mmol})$. The reaction mixture was stirred for $17 \mathrm{~h}$. Then, a part of chloroform and acetic acid was evaporated $(\mathrm{ca} .80 \mathrm{~mL})$ and a saturated aqueous $\mathrm{Na}_{2} \mathrm{~S}_{2} \mathrm{O}_{3}$ solution $(60 \mathrm{~mL})$ was added and stirred for $5 \mathrm{~min}$. The resulting mixture was extracted with $\mathrm{CH}_{2} \mathrm{Cl}_{2}$ and washed with a saturated aqueous $\mathrm{NaHCO}_{3}$ solution and $\mathrm{H}_{2} \mathrm{O}$. The organic layer was dried over $\mathrm{MgSO}_{4}$ and concentrated under vacuum. Purification by flash chromatography (pentane) afforded the titled compound as a white solid (7.83 g, 95\%). mp 42-43 ${ }^{\circ} \mathrm{C}\left[\right.$ Lit. $\left.^{35} 43-45{ }^{\circ} \mathrm{C}\right]$. IR (ATR) $v$ 1432, 1300, 1252, 916, 748, $719 \mathrm{~cm}^{-1} .{ }^{1} \mathrm{H}$ NMR $\left(\mathrm{CDCl}_{3}, 300 \mathrm{MHz}\right) \delta 7.75-7.70(\mathrm{~m}, 2 \mathrm{H}), 7.44-7.31(\mathrm{~m}, 2 \mathrm{H}), 2.57(\mathrm{~s}, 3 \mathrm{H}) .{ }^{13} \mathrm{C} \mathrm{NMR}\left(\mathrm{CDCl}_{3}\right.$, $75 \mathrm{MHz}) \delta 138.6,137.3,135.4,125.0,124.9,122.7,122.3,106.7,15.65 . \mathrm{HRMS}\left(\mathrm{ASAP}^{+}\right) \mathrm{m} / \mathrm{z}$ $[\mathrm{M}]^{+}$Calcd for $\mathrm{C}_{9} \mathrm{H}_{7} \mathrm{SBr} 225.9452$; Found 225.9455 .

3,3'-(Perfluorocyclopent-1-ene-1,2-diyl)bis(2-methylbenzothiophene) (4). To a solution of 3-bromo-2-methylbenzothiophene $(6.23 \mathrm{~g}, 27.7 \mathrm{mmol})$ in dry THF $(60 \mathrm{~mL})$ under $\mathrm{N}_{2}$ atmosphere, $n$-BuLi (19.04 mL, $30.5 \mathrm{mmol}, 1.6 \mathrm{M}$ in hexane) was added dropwise at $-78{ }^{\circ} \mathrm{C}$. The mixture was stirred for 30 minutes and octafluorocyclopentene (1.66 mL, $12.47 \mathrm{mmol})$ was added dropwise to the mixture with a cooled syringe. The resulting mixture was stirred for $2 \mathrm{~h}$ at $-78^{\circ} \mathrm{C}$, warmed to room temperature and quenched with cold water $(100 \mathrm{~mL})$. The organic phase was extracted with ether $(3 \times 50 \mathrm{~mL})$ and the organic layers were collected, washed with brine $(2 \times 50 \mathrm{~mL})$, dried over $\mathrm{MgSO}_{4}$, filtered and evaporated under vacuum. The resulting mixture was purified by flash column chromatography (100\% hexane) to give 4 as a yellow solid (3.62 $\mathrm{g}, 62 \%)$ as mixture of parallel (p) and antiparallel (ap) isomers in a ratio of 36:64. $\mathrm{mp} 153-154{ }^{\circ} \mathrm{C}$ [Lit. ${ }^{36} 154-156{ }^{\circ} \mathrm{C}$ ]. IR (ATR) $v$ 1437, 1337, 1274, 1102, 962, 755, 735, 574, $565 \mathrm{~cm}^{-1} .{ }^{1} \mathrm{H}$ NMR $\left(300 \mathrm{MHz}, \mathrm{CDCl}_{3}\right) \delta 7.72-7.58(\mathrm{~m}, 4 \mathrm{H}), 7.42-7.16(\mathrm{~m}$, $4 \mathrm{H}), 2.52(\mathrm{~s}, 6 \mathrm{H} \times 0.36, \mathrm{p}), 2.25(\mathrm{~s}, 6 \mathrm{H} \times 0.64, \mathrm{ap}) .{ }^{13} \mathrm{C} \mathrm{NMR}\left(\mathrm{CDCl}_{3}, 75 \mathrm{MHz}\right) \delta 142.8$, $142.3,138.5,138.3,124.8,124.6,124.5,122.2,122.3,122.0,119.3,15.29$. HRMS $\left(\mathrm{ASAP}^{+}\right) \mathrm{m} / z[\mathrm{M}+\mathrm{H}]^{+}$Calcd for $\mathrm{C}_{23} \mathrm{H}_{15} \mathrm{~F}_{6} \mathrm{~S}_{2}$ 469.0519; Found 469.0514.

Dibenzothienylethenes (5) and (6). A solution of 3,3'-(perfluorocyclopent-1-ene-1,2diyl)bis(2-methylbenzothiophene) $4(2.65 \mathrm{~g}, 5.66 \mathrm{mmol})$ in acetic acid $(200 \mathrm{~mL})$ was treated with water $(9.4 \mathrm{~mL})$, sulfuric acid $(4 \mathrm{~mL})$, iodine $(1.72 \mathrm{~g}, 6.79 \mathrm{mmol})$ and orthoperiodic acid (554 mg, $2.43 \mathrm{mmol}$ ) at room temperature. The mixture was stirred for $3 \mathrm{~h}$ at $70{ }^{\circ} \mathrm{C}$ and the solution was poured into water $(500 \mathrm{~mL})$. The organic phase was extracted with AcOEt $(2 \times$ $100 \mathrm{~mL})$. The organic extracts were washed with water $(100 \mathrm{~mL})$, saturated aqueous $\mathrm{NaHCO}_{3}$ solution $(100 \mathrm{~mL})$ and saturated aqueous $\mathrm{Na}_{2} \mathrm{~S}_{2} \mathrm{O}_{3}$ solution $(100 \mathrm{~mL})$. The resulting solution was dried over $\mathrm{MgSO}_{4}$, filtered and concentrated. The residue was purified flash 
chromatography (100\% hexane) to afford a white solid $(2.77 \mathrm{~g}, 72 \%)$ as a mixture of $\mathbf{5 / 6}$ in a ratio of 33/66 which was directly used in the next step.

Dibenzothienylethenes (7) and (8). Under nitrogen atmosphere, a solution of a mixture of $\mathbf{5} / \mathbf{6}$ in a ratio of 33/67 (760 mg, $0.374 \mathrm{mmol} 5$ and $0.747 \mathrm{mmol} \mathrm{6}), \mathrm{Pd}\left(\mathrm{PPh}_{3}\right)_{2} \mathrm{Cl}_{2}(137 \mathrm{mg}$, $0.195 \mathrm{mmol}), \mathrm{CuI}(411 \mathrm{mg}, 2.16 \mathrm{mmol})$ and trimethylsilylacetylene $(1.42 \mathrm{~g}, 2.16 \mathrm{mmol}) \mathrm{in}$ $\mathrm{Et}_{3} \mathrm{~N}(11 \mathrm{~mL})$ was heated at $80{ }^{\circ} \mathrm{C}$ for $15 \mathrm{~h}$. The crude mixture was hydrolyzed with water $(10$ $\mathrm{mL})$. $\mathrm{Et}_{3} \mathrm{~N}$ was removed under vacuum and the solution was extracted with $\mathrm{CH}_{2} \mathrm{Cl}_{2}(3 \times 50$ $\mathrm{mL})$. The organic extracts were washed with brine $(50 \mathrm{~mL})$, dried with $\mathrm{MgSO}_{4}$ and concentrated under reduced pressure. The residue was purified with short cake of celite followed by a flash chromatography on silica gel (100\% hexane) to afford 7 (200 $\mathrm{mg}, 95 \%$, based on $\mathbf{5}$ ) and $\mathbf{8}(449 \mathrm{mg}, 91 \%$, based on $\mathbf{6})$ as yellow solids.

Dibenzothienylethene 7 was isolated as a mixture of parallel (p) and antiparallel (ap) isomers in a ratio of 38/62. mp 121-122 ${ }^{\circ} \mathrm{C}$. IR (ATR) $v 1272,1250,1139,1110,897,841,756 \mathrm{~cm}^{-1}$. ${ }^{1} \mathrm{H}$ NMR (300 MHz, $\left.\mathrm{CDCl}_{3}\right) \delta 7.83-7.19(\mathrm{~m}, 7 \mathrm{H}), 2.49(\mathrm{~s}, 6 \mathrm{H} \times 0.38, \mathrm{p}), 2.23(\mathrm{~s}, 3 \mathrm{H} \times 0.62$, ap), $2.22\left(\mathrm{~s}, 3 \mathrm{H} \times 0.62\right.$, ap), $0.30\left(\mathrm{~s}, 9 \mathrm{H} \times 0.62\right.$, ap), $0.27(\mathrm{~s}, 9 \mathrm{H} \times 0.38, \mathrm{p}) .{ }^{13} \mathrm{C} \mathrm{NMR}\left(\mathrm{CDCl}_{3}\right.$, $75 \mathrm{MHz}) \delta 144.6,144.1,142.8,142.4,138.4,138.3,138.2,128.5,128.3,125.9,125.7,124.8$, $124.6,122.3,122.0,121.9,119.5,119.2,104.9,95.2,94.9,88.2,86.1,15.4,15.2,0.1$. HRMS (ES $\left.{ }^{-}\right) m / z[\mathrm{M}-\mathrm{H}]^{-}$Calcd for $\mathrm{C}_{28} \mathrm{H}_{21} \mathrm{~F}_{6} \mathrm{~S}_{2} \mathrm{Si}$ 563.0758; Found 563.0748.

Dibenzothienylethene 8 was isolated as a mixture of parallel (p) and antiparallel (ap) isomers in a ratio of $41 / 59 . \mathrm{mp} 198-199^{\circ} \mathrm{C}$; IR (ATR) $v 1462,1343,1271,1146,1106,840,820 \mathrm{~cm}^{-}$ ${ }^{1} .{ }^{1} \mathrm{H}$ NMR $\left(300 \mathrm{MHz}, \mathrm{CDCl}_{3}\right) \delta 7.81(\mathrm{~s}, 2 \mathrm{H} \times 0.59$, ap), $7.73(\mathrm{~s}, 2 \mathrm{H} \times 0.41, \mathrm{p}), 7.53(\mathrm{~d}, 2 \mathrm{H} \times$ $0.59, J=8.3 \mathrm{~Hz}, \mathrm{ap}), 7.47-7.38(\mathrm{~m}, 2 \mathrm{H}), 7.24(\mathrm{~s}, 2 \mathrm{H} \times 0.41, \mathrm{p}), 2.46(\mathrm{~s}, 6 \mathrm{H} \times 0.41, \mathrm{p}), 2.18(\mathrm{~s}$, $6 \mathrm{H} \times 0.59$, ap), $0.26\left(\mathrm{~s}, 18 \mathrm{H} \times 0.59\right.$, ap), $0.24(\mathrm{~m}, 18 \mathrm{H} \times 0.41, \mathrm{p}) .{ }^{13} \mathrm{C} \mathrm{NMR}\left(\mathrm{CDCl}_{3}, 75 \mathrm{MHz}\right)$ $\delta$ 144.6, 144.1, 138.1, 128.4 128.4, 125.9, 125.8, 121.9, 121.6, 119.5, 119.3, 104.8, 95.2, 15.4, 0.1. HRMS $\left(\mathrm{ES}^{+}\right) \mathrm{m} / z[\mathrm{M}+\mathrm{Na}]^{+}$Calcd for $\mathrm{C}_{33} \mathrm{H}_{30} \mathrm{~F}_{6} \mathrm{NaS}_{2} \mathrm{Si}_{2}$ 683.1129; Found 683.1145.

Dibenzothienylethene (9(0)). A solution of $7(100 \mathrm{mg}, 0.177 \mathrm{mmol})$ in a mixture of $\mathrm{CH}_{2} \mathrm{Cl}_{2}(20 \mathrm{~mL})$ and $\mathrm{MeOH}(10 \mathrm{~mL})$ was treated with $\mathrm{K}_{2} \mathrm{CO}_{3}(600 \mathrm{mg}, 4.35 \mathrm{mmol})$ under nitrogen. The resulting mixture was stirred for $1 \mathrm{~h}$ at room temperature and quenched with $\mathrm{NH}_{4} \mathrm{Cl}(50 \mathrm{~mL})$. The organic phase was extracted with $\mathrm{CH}_{2} \mathrm{Cl}_{2}(3 \times 50 \mathrm{~mL})$ and washed with water $(2 \times 20 \mathrm{~mL})$. The resulting solution was dried over $\mathrm{MgSO}_{4}$, filtered and concentrated to give 9(o) as a yellow solid (83.6 $\mathrm{mg}, 96 \%$ ) as a mixture of parallel (p) and antiparallel (ap) isomers in a ratio of $37 / 63 . \mathrm{mp}: 163-164{ }^{\circ} \mathrm{C}$. IR (ATR) $v 3302,2108,1345,1273,1101,965$, $725,646 \mathrm{~cm}^{-1} .{ }^{1} \mathrm{H}$ NMR $\left(300 \mathrm{MHz}, \mathrm{CDCl}_{3}\right) \delta 7.88-7.12(\mathrm{~m}, 7 \mathrm{H}), 3.12(\mathrm{~s}, 1 \mathrm{H} \times 0.63, \mathrm{ap}), 3.06$ 
$(\mathrm{s}, 1 \mathrm{H} \times 0.37, \mathrm{p}), 2.49(\mathrm{~s}, 6 \mathrm{H} \times 0.37, \mathrm{p}), 2.23\left(\mathrm{~s}, 3 \mathrm{H} \times 0.63\right.$, ap), $2.21(\mathrm{~s}, 3 \mathrm{H} \times 0.63, \mathrm{ap}) .{ }^{13} \mathrm{C}$ $\mathrm{NMR}\left(\mathrm{CDCl}_{3}, 75 \mathrm{MHz}\right) \delta 144.8,144.2,142.9,142.4,138.5,138.4,138.2,138.1,128.6$, $128.4,126.1,125.9,124.8,124.7,124.6,122.3,122.1,122.1,119.4,119.2,118.4,83.5,77.9$, 15.4, 15.3. HRMS (ASAP $\left.{ }^{+}\right) m / z[\mathrm{M}]^{+}$Calcd for $\mathrm{C}_{25} \mathrm{H}_{14} \mathrm{~F}_{6} \mathrm{~S}_{2} 492.0441$; Found 492.0435 .

Dibenzothienylethene (10(o)). A solution of $8(231 \mathrm{mg}, 0.35 \mathrm{mmol})$ in a mixture of $\mathrm{CH}_{2} \mathrm{Cl}_{2}(20 \mathrm{~mL})$ and $\mathrm{MeOH}(10 \mathrm{~mL})$ was treated with $\mathrm{K}_{2} \mathrm{CO}_{3}(1.38 \mathrm{~g}, 10 \mathrm{mmol})$ under nitrogen. The resulting mixture was stirred for $1 \mathrm{~h}$ at room temperature and quenched with saturated aqueous $\mathrm{NH}_{4} \mathrm{Cl}$ solution $(50 \mathrm{~mL})$. The organic phase was extracted with $\mathrm{CH}_{2} \mathrm{Cl}_{2}(3$ $\times 50 \mathrm{~mL})$ and washed with water $(2 \times 50 \mathrm{~mL})$. The organic extracts were dried over $\mathrm{MgSO}_{4}$, filtered and concentrated under vacuum to give 10(o) as a yellow solid (179 $\mathrm{mg}, 99 \%)$ as mixture of parallel (p) and antiparallel (ap) isomers in a ratio of 40/60. mp: 194-195 ${ }^{\circ} \mathrm{C}$. IR $\left(\right.$ ATR) $v$ 3302, 2111, 1461, 1336, 1269, 1106, 965, 876, $816 \mathrm{~cm}^{-1} .{ }^{1} \mathrm{H}$ NMR $(300 \mathrm{MHz}$, $\left.\mathrm{CDCl}_{3}\right) \delta 7.84(\mathrm{~s}, 2 \mathrm{H} \times 0.6$, ap), $7.75(\mathrm{~s}, 2 \mathrm{H} \times 0.4, \mathrm{p}), 7.57(\mathrm{~d}, 2 \mathrm{H} \times 0.6, J=8.3 \mathrm{~Hz}, \mathrm{ap}), 7.48$ $(\mathrm{m}, 2 \mathrm{H}), 7.30(\mathrm{~m}, 2 \mathrm{H} \times 0.4, \mathrm{p}), 3.12(\mathrm{~s}, 2 \mathrm{H} \times 0.6, \mathrm{ap}), 3.08(\mathrm{~s}, 2 \mathrm{H} \times 0.4, \mathrm{p}), 2.48(\mathrm{~s}, 6 \mathrm{H} \times 0.4$, p), $2.20\left(\mathrm{~s}, 6 \mathrm{H} \times 0.6\right.$, ap). ${ }^{13} \mathrm{C} \mathrm{NMR}\left(\mathrm{CDCl}_{3}, 75 \mathrm{MHz}\right) \delta 144.8,138.4,138.2,128.6,128.5$, 126.2, 126.0, 122.0, 121.8, 119.3, 118.5, 83.4, 77.9, 15.4. HRMS $\left(\mathrm{ASAP}^{+}\right) m / z[\mathrm{M}]^{+}$Calcd for $\mathrm{C}_{27} \mathrm{H}_{14} \mathrm{~F}_{6} \mathrm{~S}_{2}$ 516.0441; Found 516.0432.

Dibenzothienylethene (11). A solution of $8(300 \mathrm{mg}, 0.454 \mathrm{mmol})$ in $\mathrm{CH}_{2} \mathrm{Cl}_{2}(15 \mathrm{~mL})$ under inert atmosphere was treated with $m$-CPBA (673 mg, $2.73 \mathrm{mmol}, 70 \%$ in water) at 0 ${ }^{\circ} \mathrm{C}$ and the resulting mixture was stirred for $48 \mathrm{~h}$ at $25{ }^{\circ} \mathrm{C}$. The organic phase was extracted with $\mathrm{CH}_{2} \mathrm{Cl}_{2}(3 \times 50 \mathrm{~mL})$ and washed with water $(2 \times 10 \mathrm{~mL})$. The organic extracts were dried over $\mathrm{MgSO}$ 4, filtered and concentrated under vacuum to give 11 as a yellow solid (329 $\mathrm{mg}, 89 \%$ ) as a mixture of parallel (p) and antiparallel (ap) isomers in a ratio of 52/48. mp 151-153 ${ }^{\circ} \mathrm{C}$. IR (ATR) v 2158, 1697, 1317, 1145, $842 \mathrm{~cm}^{-1} .{ }^{1} \mathrm{H}$ NMR (300 MHz, $\left.\mathrm{CDCl}_{3}\right)$ $\delta 7.81(\mathrm{~s}, 1 \mathrm{H}), 7.77(\mathrm{~s}, 1 \mathrm{H}), 7.63(\mathrm{~d}, J=7.7 \mathrm{~Hz}, 1 \mathrm{H}), 7.47$ (d, $J=7.7 \mathrm{~Hz}, 1 \mathrm{H}), 7.04(\mathrm{~m}, 2 \mathrm{H})$, $2.18(\mathrm{~s}, 3 \mathrm{H}), 2.03(\mathrm{~s}, 3 \mathrm{H}), 0.25(\mathrm{~s}, 18 \mathrm{H}) ;{ }^{13} \mathrm{C} \mathrm{NMR}\left(\mathrm{CDCl}_{3}, 75 \mathrm{MHz}\right) \delta 145.0,144.3,137.0$, $136.8,135.5,128.6,126.7,126.5,126.2,123.6,122.2,122.1,102.0,100.9,9.1,-0.22$. HRMS (ES $) m / z[\mathrm{M}-\mathrm{H}]^{-}$Calcd for $\mathrm{C}_{33} \mathrm{H}_{29} \mathrm{O}_{4} \mathrm{~F}_{6} \mathrm{~S}_{2} \mathrm{Si}_{2}$ 723.0950; Found 723.0969.

Covalent printing on cellulose paper with dibenzothienylethenes 9(o) - Cell-DBE-1. A piece of Cell-Dis (12 mg), wedged between a photomask and an aluminium plate $(2 \times 2.5$ $\mathrm{cm})$, was immersed in the solution of dibenzothienylethenes $9(\mathbf{0})(135 \mathrm{mg}, 0.27 \mathrm{mmol})$ and 2,2-dimethoxy-2-phenylacetophenone (DMPA, $5 \mathrm{mg}, 0.02 \mathrm{mmol}$ ) in DMSO (6 mL). The solution, under vigorous stirring, was irradiated with a Xenon lamp $(50 \mathrm{~W})$ for 150 minutes. 
The paper was washed successively with $\mathrm{EtOH}, \mathrm{MeOH}$, acetone and $\mathrm{CH}_{2} \mathrm{Cl}_{2}$, dried under vacuum and stored under argon.

Covalent printing on cellulose paper with dibenzothienylethenes 10(o) - Cell-DBE-2. A piece of Cell-Dis (12 mg), wedged between a photomask and an aluminium plate $(2 \times 2.5$ $\mathrm{cm})$, was immersed in the solution of dibenzothienylethenes $\mathbf{1 0}(\mathbf{o})(140 \mathrm{mg}, 0.27 \mathrm{mmol})$ and 2,2-dimethoxy-2-phenylacetophenone (DMPA, $5 \mathrm{mg}, 0.02 \mathrm{mmol}$ ) in DMSO (6 mL). The solution, under vigorous stirring, was irradiated with a Xenon lamp $(50 \mathrm{~W})$ for 150 minutes. The paper was washed successively with $\mathrm{EtOH}, \mathrm{MeOH}$, acetone and $\mathrm{CH}_{2} \mathrm{Cl}_{2}$, dried under vacuum and stored under argon.

Computational details. All theoretical calculations have been performed with the Gaussian 16 program. ${ }^{37}$ The ground-state geometries of the different dyes have been optimized at the PBE0/6-31G(d) level, ${ }^{38}$ taking into account dispersion effects through the use of the D3-BJ approach. ${ }^{39}$ These geometry optimization were made using a tight convergence threshold and the so-called ultrafine DFT integration grid. Next, the minimum nature of all optimized geometries was confirmed by a frequency calculation that returned no imaginary frequency. The excited-state were explored using TD-DFT with the same PBE0 functional but a diffuse containing atomic basis set, namely $6-31+\mathrm{G}(\mathrm{d})$. The thermal transition state between the open and closed forms was determined at the PBE0/6-31G(d) level using the brokensymmetry (BS-DFT) approach and it was verified that the final vibrational mode indeed corresponds to the cyclization process. During all calculations, solvent effects $\left(\mathrm{CH}_{2} \mathrm{Cl}_{2}\right)$ were accounted fro using the Polarizable Continuum Model (PCM), ${ }^{40}$ in its linear-response nonequilibrium form for the TD-DFT part of the calculation.

\section{口 RESULTS AND DISCUSSION}

Synthesis of dibenzothienylethenes. We recently reported the concept of covalent printing onto cellulose paper. ${ }^{31}$ The covalent printing strategy uses photoresponsive papers functionalized with dithiodiglycolic ester which upon light irradiation allows thiol-X ligations of chromophoric inks with a powerful spatio-temporal control. The application of the covalent printing strategy to the fabrication of photochromic papers required the synthesis of dibenzothienylethenes bearing reactive alkyne groups for thiol-yne ligations onto the surface of cellulose paper.

The dibenzothienylethene backbone 4 was prepared in two steps from commercially available 2-methylbenzothiophene 1 by adaptation of literature procedures (Scheme 1). ${ }^{41}$ 
Bromination of 2-methylbenzothiophene 1 with NBS followed by lithium-halogen exchange with $n$-Buli furnished the corresponding lithiated benzothiophene derivative $\mathbf{2}$ which reacted with octafluorocyclopentene 3 at $-78{ }^{\circ} \mathrm{C}$ to give 1,2-bis-(2-methylbenzo[b]thiophen-3yl)perfluorocyclopentene 4 in $62 \%$ yield over two steps. Iodination of the benzothiophene units furnished an inseparable mixture of mono- and diiodinated dibenzothienylethenes $\mathbf{5 / 6}$, in a ratio of $1 / 2$, respectively, and $72 \%$ yield. The subsequent introduction of alkyne functional groups through a Sonogashira reaction with trimethylsilylacetylene was carried out on the iodinated mixture 5/6, furnishing the corresponding dibenzothienylethenes $\mathbf{7}$ and $\mathbf{8}$ which were separated by flash chromatography. The cleavage of the trimethylsilyl protecting group on 7 and 8 with $\mathrm{K}_{2} \mathrm{CO}_{3}$ in $\mathrm{CH}_{2} \mathrm{Cl}_{2} / \mathrm{MeOH}$ proceeded smoothly to give the expected terminal alkynes 9(o) and 10(0) which were immediately engaged for the covalent printing of cellulose paper due to their rapid degradation upon storage. We also envisaged the preparation of the sulfonyl derivative 12 since it has been reported that the oxidation of benzothienyl moieties significantly increase the fluorescence quantum yield of the closed form, as compared to the corresponding unoxidized dibenzothienylethenes. ${ }^{42}$ The oxidized photochromic compound 12 was tentatively prepared in two steps by sulfur oxidation of $\mathbf{8}$ with $m$-CPBA, furnishing $\mathbf{1 1}$ as intermediate, followed by trimethylsilyl cleavage. Unfortunately, the oxidized derivative $\mathbf{1 2}$ proved to be unstable and could not be obtained in pure form for further covalent printing on cellulose paper. 

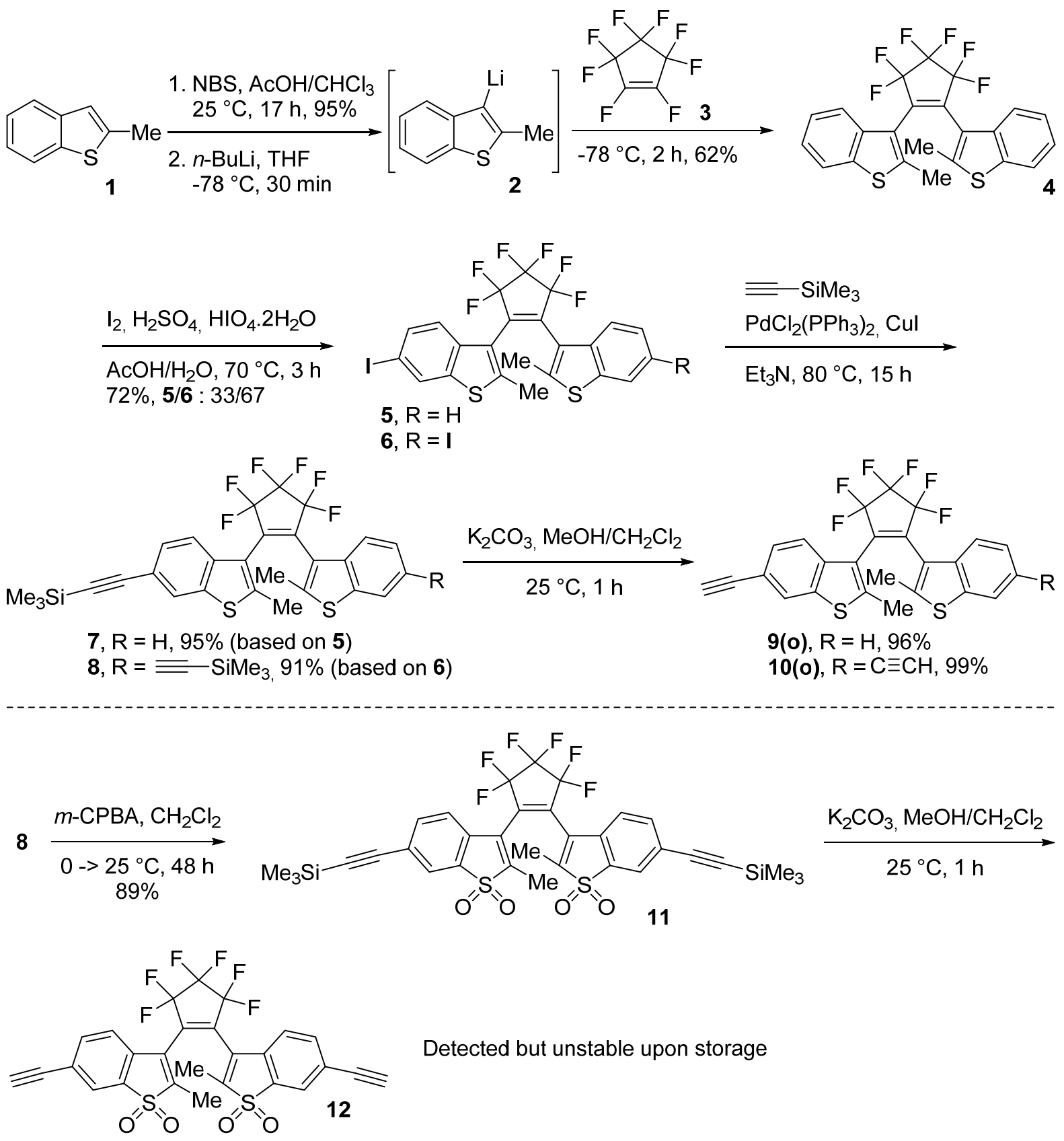

SCHEME 1. Preparation of dibenzothienylethenes bearing alkyne functional groups

The covalent printing of $\mathbf{9 ( 0 )}$ and $\mathbf{1 0 ( 0 )}$ on photoactive cellulose paper (Cell-Dis), through a thiol-yne ligation, was carried out following an adaptation of our recently developed protocol. ${ }^{31}$ Cell-Dis, prepared by grafting of dithiodiglycolic acid on mercerized cellulose paper, was inserted in a sample holder consisting of two aluminum plates; the top plate being machined with the letter "U". Upon immersion in a solution of 9(o) or 10(o) in DMSO, also containing 2,2-dimethoxy-2-phenylacetophenone (DMPA) as radical initiator, Cell-Dis was irradiated with a Xenon lamp $(60 \mathrm{~W})$ to print the letter "U" (Scheme 2). 

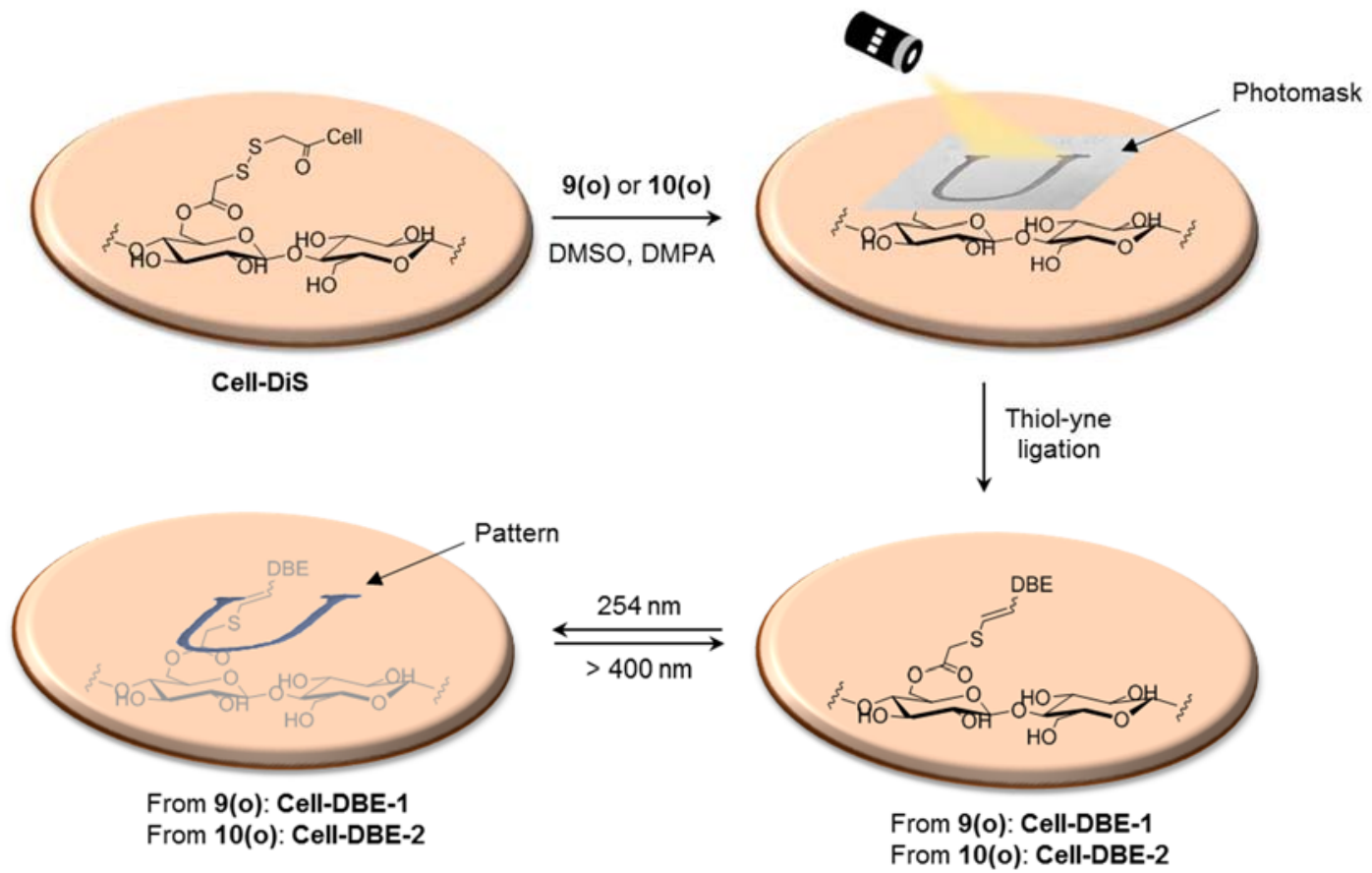

SCHEME 2. General strategy for the covalent printing of photochromic compounds 9(o) and $10(0)$.

Material characterization. The covalent printing of 9(o) and 10(o) onto Cell-DiS was followed by Fourier-transform infrared spectroscopy (FTIR) and X-ray photoelectron spectroscopy (XPS) analyses (Figure 1). The appearance of a new band at $c a .1645 \mathrm{~cm}^{-1}$ on the FTIR spectra of Cell-DBE-1 and Cell-DBE-2 characteristic of $\mathrm{C}=\mathrm{C}$ stretching frequencies of the dibenzothienylethene backbone, successfully confirmed the grafting. The band at $c a$. $1725 \mathrm{~cm}^{-1}$ accounts for the $\mathrm{C}=\mathrm{O}$ stretching vibration of the ester groups confirming that the covalent printing conditions did not affect the thiomethylglycolate function. The remaining bands between 400 to $1500 \mathrm{~cm}^{-1}$ are characteristic of the finger print of the cellulose backbone while the bands in the region of $3100-3400 \mathrm{~cm}^{-1}$ are attributed to the stretching of $\mathrm{O}-\mathrm{H}$ bonds. The XPS spectra of Cell-DBE-1 and Cell-DBE-2 also attested the succesful grafting of 9(o) and 10(o), respectively, through the presence of F1s peaks at $c a .688 \mathrm{eV}$. 

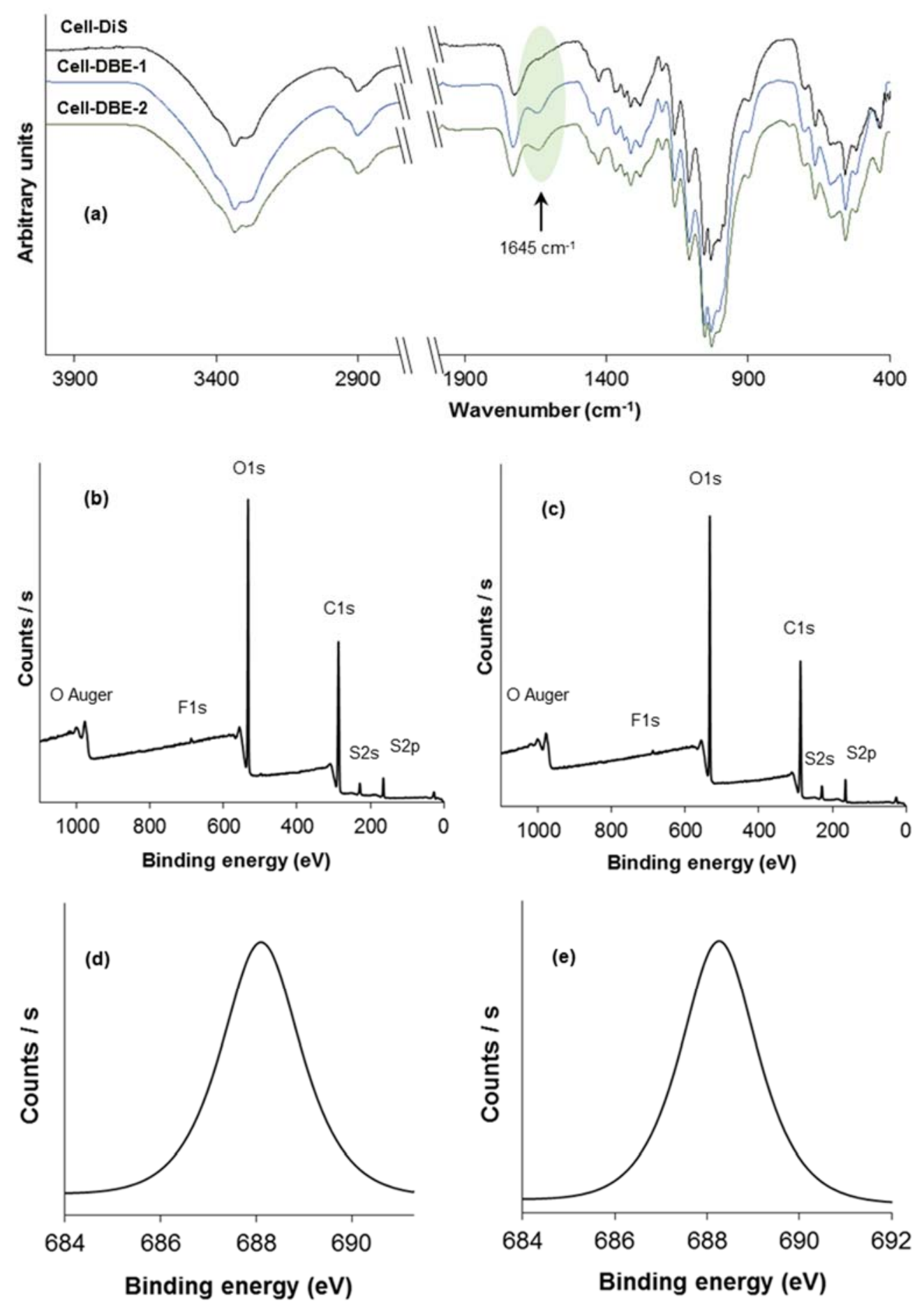

Figure 1. (a) FTIR spectra of Cell-DiS, Cell-DBE-1 and Cell-DBE-2. (b) Survey scan spectra of Cell-DBE-1. (c) Survey scan spectra of Cell-DBE-2. (d) High-resolution F1s spectrum of Cell-DBE-1. (e) High-resolution F1s spectrum of Cell-DBE-2.

The thermal stability of Cell-DBE-1 and Cell-DBE-2 were assessed using thermogravimetric analysis (TGA) experiments under $\mathrm{N}_{2}$ atmosphere (Figure 2) and 
compared to pristine cellulose paper. The mass loss of ca. $4 \%$ below $200{ }^{\circ} \mathrm{C}$ for the three samples is attributed to the desorption of volatiles such as residual solvents and moisture.

Cell-DBE-1 and Cell-DBE-2 display very similar stability profiles and are stable until 250 ${ }^{\circ} \mathrm{C}$; Cell showing a slighly increased stability, up to 300 . The sudden mass loss at $260{ }^{\circ} \mathrm{C}$ for Cell-DBE-1 and Cell-DBE-2 can be explained by the elimination of the grafted photochromic moieties. This result suggests that Cell-DBE-1 and Cell-DBE-2 are stable in a large range of temperatures from 25 to $250{ }^{\circ} \mathrm{C}$.

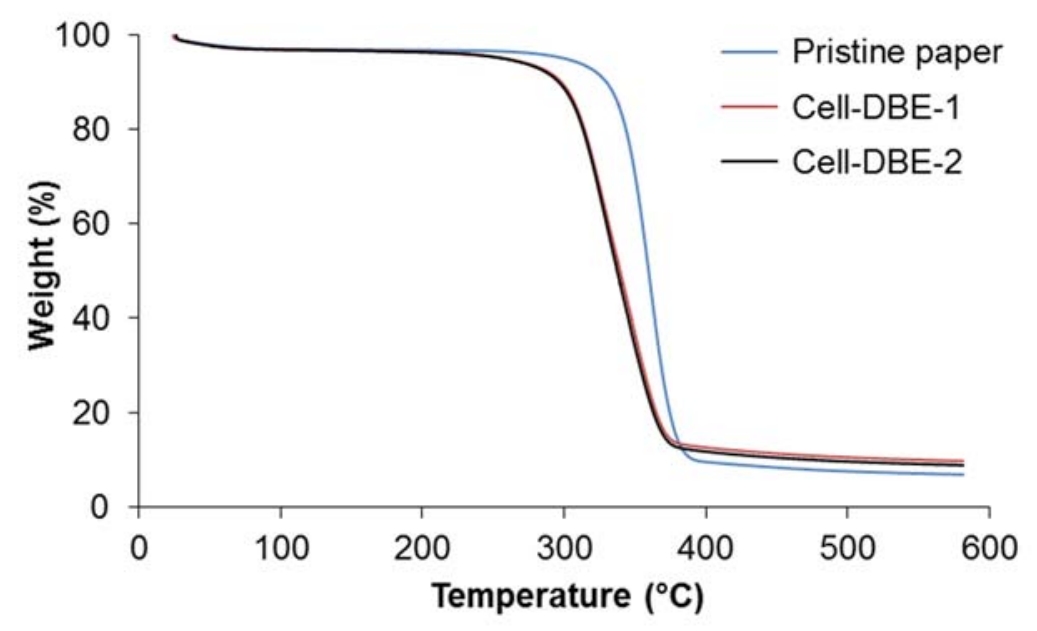

Figure 2. Thermogravimetric analysis of Cell, Cell-DBE-1 and Cell-DBE-2.

The atomic composition of the patterned surface was determined by XPS and the degree of substitution (DS) was calculated to be $c a .1 \%$ for both paper. This value means that 1 glucose unit is functionalized with photochromic compounds every 100 glucose units. As the degree of substitution of Cell-DiS by dithiodiglycolic acid units was $c a .14 \%$, the yield of the covalent printing was calculated to be $c a .7 \%$. While the DS of the photochromic papers and the associated covalent printing yields could be hastily considered as unsatisfactory, the absorbance of the closed form at very long-wavelength allowed to follow the photochromic behavior of the patterned papers by naked eyes (vide infra). Moreover, a high concentration of the dyes onto the surface of cellulose paper might generate detrimental photochromic effects due to cross interactions.

Photophysical properties. In order to evaluate the influence of the cellulose matrix on the photophysical properties of dibenzothienylethenes 9(o) and 10(o), we initially recorded their absorption spectra in solution for comparison with Cell-DBE-1 and Cell-DBE-2 (Figure 3). We also used theoretical chemistry to model their properties (vide infra). 

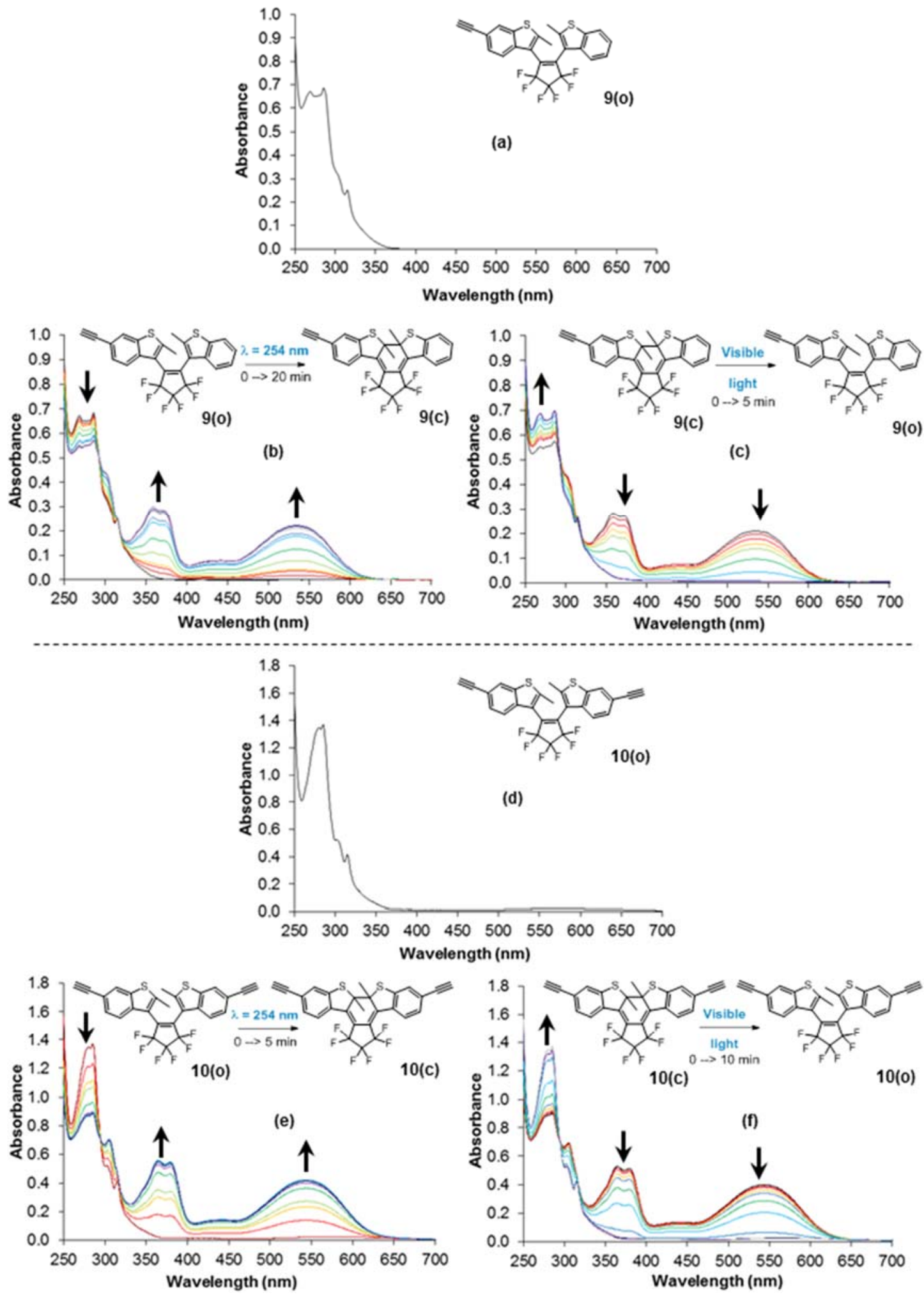

FIGURE 3. (a) Absorbtion spectra of 9(o) in the ground state. Time evolution of the absorbance of 9(o) (b) under irradiation at $254 \mathrm{~nm}$, (c) under visible light. (d) Absorbtion spectra of 10(o) in the ground state. Time evolution of the absorbance of 10(0) (e) under irradiation at $254 \mathrm{~nm}$, (f) under visible light. All data obtained in $\mathrm{CH}_{2} \mathrm{Cl}_{2}$ at $4 \times 10^{-5} \mathrm{M}$ and 25 ${ }^{\circ} \mathrm{C}$. 
The absorption spectra of $\mathbf{9}(\mathbf{o})$ and $\mathbf{1 0}(\mathbf{o})$, recorded in $\mathrm{CH}_{2} \mathrm{Cl}_{2}\left(4 \times 10^{-5} \mathrm{M}\right)$ at $25^{\circ} \mathrm{C}$, only show absorption bands in the UV region $(<350 \mathrm{~nm})$, as expected. Upon light irradiation of 9(o) and 10(o) at $254 \mathrm{~nm}$, the corresponding colorless solutions turn deep pink and purple, respectively. Such color change indicates the successful $6 \pi$-electrocyclization of the ring-open isomers 9(o) and 10(0) to the corresponding closed forms 9(c) and 10(c), respectively. The photocyclization, upon irradiation at $254 \mathrm{~nm}$, is evidenced by the gradual decay of bands in the UV region $(\lambda<300 \mathrm{~nm})$ together with the appearance of strong absorption bands at 359 , 371 and $535 \mathrm{~nm}$ for the closed-ring isomer 9(c), and 364, 379 and $546 \mathrm{~nm}$ for the closed-ring isomer 10(c). These results show that the presence of a second alkyne function in 10(c) with respect to 9(c) redshifts absorption bands due to the increased conjugation (see also calculations below). The photostationary state is reached after 20 minutes of irradiation for 9(c) and $5 \mathrm{~min}$ for $\mathbf{1 0}(\mathbf{c})$. The cycloreversion gradually occurs under daylight (standard lightning in the laboratory) as indicated by the decay of the intensities of the bands in the region of 340-550 $\mathrm{nm}$ and the complete bleaching of the solution. The photostationary state is obtained after $5 \mathrm{~min}$ for $\mathbf{9 ( 0 )}$ and $10 \mathrm{~min}$ for $\mathbf{1 0 ( 0 )}$ under daylight. We also confirmed that 9(o) and 10(0) are both P-type photochromic compounds as thermal relaxation is not observed upon prolonged heating in the dark (refluxing $\mathrm{CH}_{2} \mathrm{Cl}_{2}$ for 2 hours).

We have performed Density Functional Theory (DFT) calculations to characterize dyes 9(o), 10(o), 9(c), and 10(c) (see Experimental Section for computational details). For the open-ring structures, the relative free energies of the parallel and anti-parallel conformers are nearly equal (difference $<0.5 \mathrm{kcal}_{\mathrm{mol}}{ }^{-1}$ ) indicating that, consistently with experiment, there is therefore only half of the DBE that can undergo photochromism, a usual outcome in diaryletheyne switches. The closed-ring forms $\mathbf{9 ( c )}$ and 10(c) are respectively less stable by

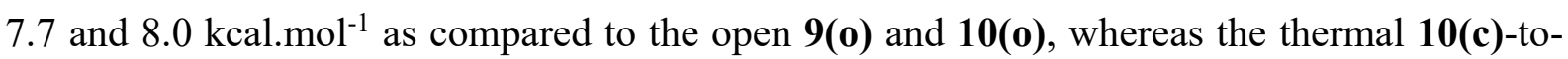
10(o) barrier is as large as $36 \mathrm{kcal}_{\mathrm{mol}}{ }^{-1}$, consistent with the observed P-type photochromism. We also carried out TD-DFT calculations to probe the nature of the excited-states. For the hallmark visible absorption of the closed forms, TD-DFT returns transitions at $567 \mathrm{~nm}$ $(f=0.36)$ and $584 \mathrm{~nm}(f=0.47)$ for $\mathbf{9 ( c )}$ and $\mathbf{1 0}(\mathbf{c})$, respectively. These values are in good agreement with the experimental ones (see Figure 3), the redshift upon addition of a second ethynyl group being reproduced. As expected, these transitions are attributed to a HOMOLUMO transition. These orbitals are displayed on Figure 4. As can be seen, both orbitals are significantly delocalized on the ethynyl segment(s), consistently with an increase of delocalization and hence a redshift of the absorption spectra. 

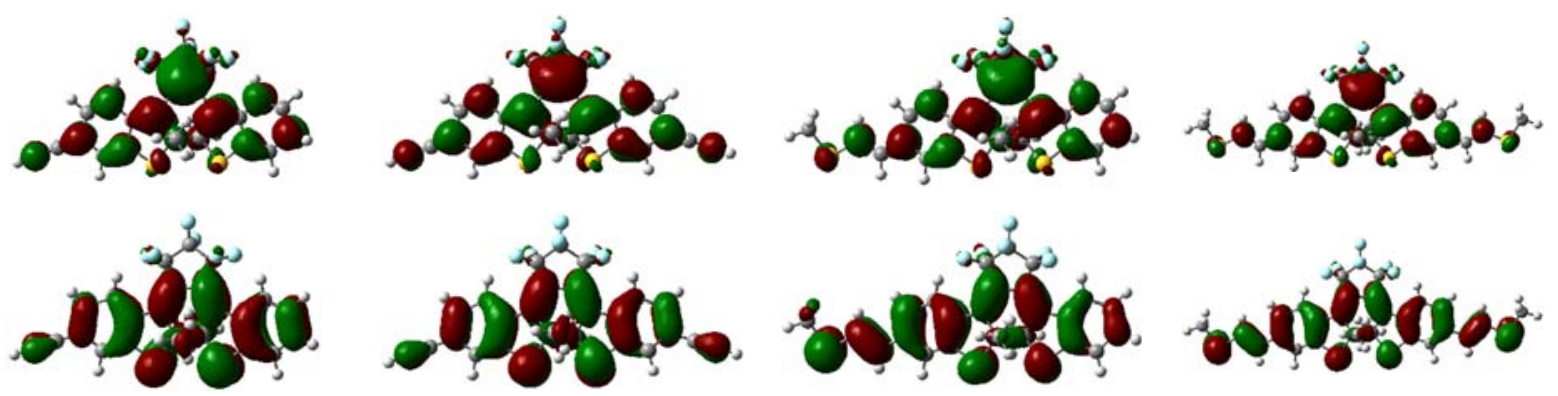

Figure 4. Representation of the PCM $\left(\mathrm{CH}_{2} \mathrm{Cl}_{2}\right)-\mathrm{PBE} 0-\mathrm{D} 3^{\mathrm{BJ}} / 6-31+\mathrm{G}(\mathrm{d})$ frontier orbitals (bottom: HOMO, top: LUMO) for dyes 9(c) (leftmost), 10(c) (center left) and the dyes corresponding to DBE anchored onto cellulose Cell-DBE-1 (9'(c), center right) and CellDBE-2 (10'(c), rightmost).

Reflective UV-Vis spectroscopy was used to follow the photochromic behavior of CellDBE-1 and Cell-DBE-2 (Figure 5). Due to the presence of whitening agents, absorbing between 250 to $350 \mathrm{~nm}$, in commercially available cellulose paper, we restricted the absorbance recording at wavelengths $>350 \mathrm{~nm}$ to follow the characteristic bands of the ringclosed isomers at $c a .540 \mathrm{~nm}$. The time evolution of the absorption in the 400-750 nm window was followed upon irradiation at $254 \mathrm{~nm}$. While the ground-state absorption spectra of Cell-DBE-1 and Cell-DBE-2 does not show any band between 400 and $750 \mathrm{~nm}$, a new band centered at 534 and $548 \mathrm{~nm}$ for Cell-DBE-1 and Cell-DBE-2, respectively, appear after 10 seconds of irradiation. These measurements show that the $\lambda \max$ of the absorption bands at ca. $540 \mathrm{~nm}$ are similar to the one of 9(o) and 10(0) as the band was blue-shifted by $1 \mathrm{~nm}$ on Cell-BDE-1 and red-shifted by $2 \mathrm{~nm}$ on Cell-DBE-2, respectively. We have also modeled at the TD-DFT level the properties of the DBE presenting a form equivalent to the one after grafting, that is, the DBE in which we replaced the ethynyl segment(s) by 2-methylthiovinyl moiety(ies), and we denote this species 9' and 10'. The thermodynamic properties were rather comparable to the one of the original switches with nearly equal free energies for the parallel and anti-parallel conformers and a closed form less stable by 6.4 and $4.9 \mathrm{kcal}^{\mathrm{mol}} \mathrm{m}^{-1}$ than the open form for 9' and 10', respectively. The thermal $\mathbf{1 0}^{\prime}$ (c)-to-10'(o) barrier is as large as 37 kcal.mol ${ }^{-1}$, very close to the value obtained for 10 (vide supra). The PCM $\left(\mathrm{CH}_{2} \mathrm{Cl}_{2}\right)$-TD-DFT calculations predict that $\mathbf{9}^{\prime}(\mathbf{c})$ and $\mathbf{1 0}^{\prime}(\mathbf{c})$ have their lowest transition at $581 \mathrm{~nm}(f=0.66)$ and $617 \mathrm{~nm}(f=1.07)$ indicating significant bathochromic and hyperchromic shifts compared to 9(c) and $\mathbf{1 0}(\mathbf{c})$ in the same conditions. The strong increase of the oscillator strength is a positive news as it means that even a small ratio of grafted photochrome could be detected. The predicted bathochromic displacements are a logical consequence of the stronger $\pi$ - 
conjugation in double than triple bonds (see the extended HOMO and LUMO of 9'(c) and $\mathbf{1 0}^{\prime}$ (c) in Figure 4), but remains unseen experimentally when grafting the dyes on the paper, which hints that cellulose induces a small hypsochromic shift compared to solution. In any case, these theoretical and experimental results suggest that the conjugated $\pi$-electron systems were not strongly affected by the grafting, highlighting the high value of our thiol-X ligation for preserving the photophysical properties of photochromic compounds. Comparing Cell-DBE-1 and Cell-DBE-2 was also informative as the bi-functional photochromic compound grafted to Cell-DBE-2 redshifts the absorption band by $12 \mathrm{~nm}$ with respect to Cell-BDE-1 (534 vs. $548 \mathrm{~nm}$ ). The photostationary state was reached after 20 and 60 minutes for Cell-BDE-1 and Cell-DBE-2, respectively. The reversible photochromic switches were evidenced upon subsequent exposure of the patterned paper to daylight. Then band centered at ca. $540 \mathrm{~nm}$ completely disappeared after $40 \mathrm{~min}$ for Cell-BDE-1 and $60 \mathrm{~min}$ Cell-DBE-2. 

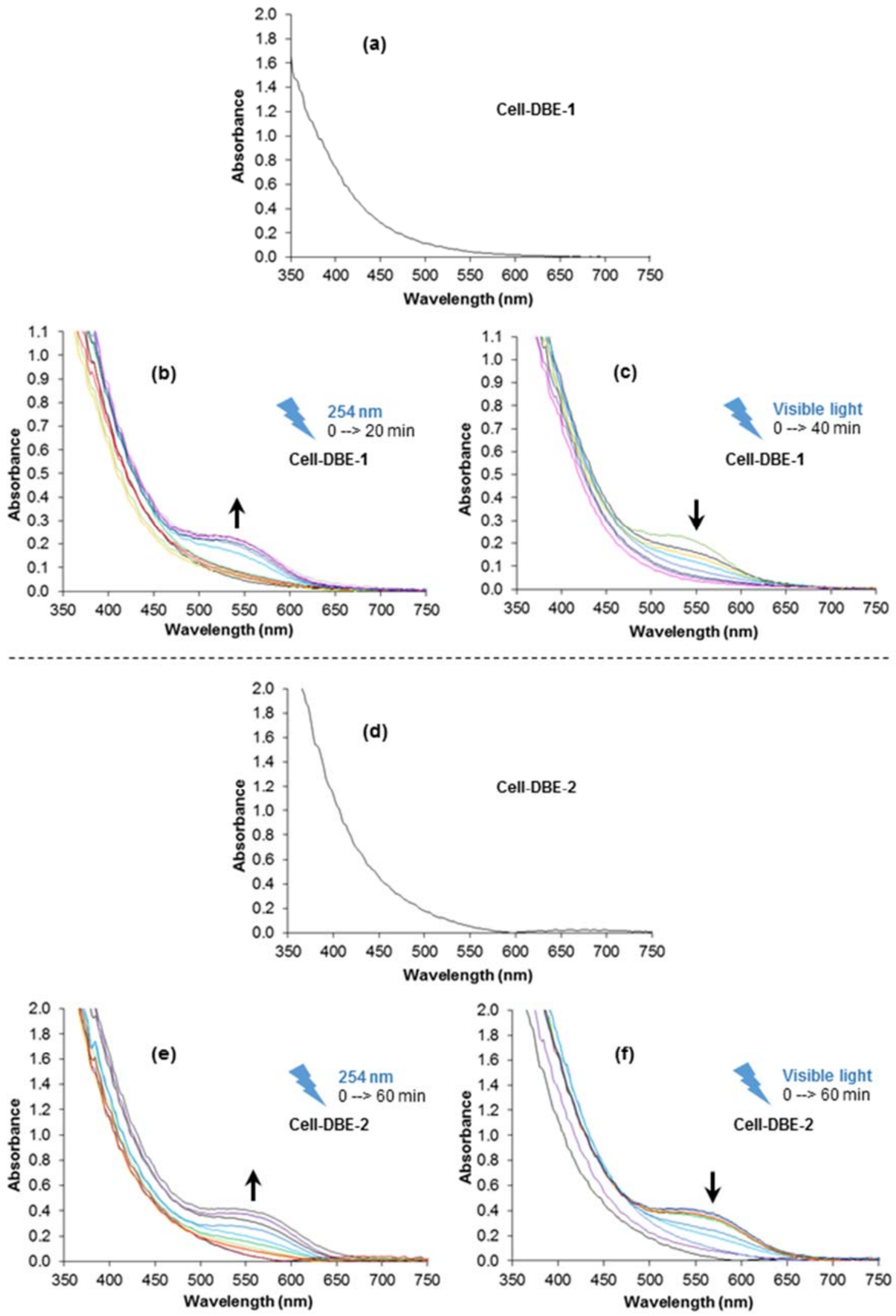

FiguRE 5. (a) Absorbtion spectra of Cell-DBE-1 in the ground state. Time evolution of the absorbance of Cell-DBE-1 (b) under irradiation at $254 \mathrm{~nm}$, (c) under visible light. (d) 
Absorbtion spectra of Cell-DBE-2 in the ground state. Time evolution of the absorbance of Cell-DBE-2 (e) under irradiation at $254 \mathrm{~nm}$, (f) under visible light.

The photochromic behavior of our patterned paper is illustrated on Figure 6. Pictures of patterned papers Cell-BDE-1 and Cell-DBE-2 under daylight (Figures 6a and 6c, leftmost) and after irradiation at $254 \mathrm{~nm}$ (Figures 6a and 6c, rightmost) show the strong colorationdiscoloration switch. An excellent color contrast and a good resolution of the printed letter "U" can be observed for both papers. The precision covalent printing allows patterns with line thickness of $c a .250-500 \mu \mathrm{M}$. Increasing the precision to line thickness $<200 \mu \mathrm{M}$ would not be relevant for cellulosic material due to a high heterogeneity of the surface composed of fibers with a diameter usually ranging from 10 to $100 \mu \mathrm{m}$. The grafting mostly occurs on the surface of the paper as the photochromic patterns are not visible on the opposite side of CellBDE-1 and Cell-DBE-2. The repeatability of the photochromic behavior was studied by applying 18 successive write-erase cycles and neither significant color change nor color intensity were observed. Indeed, as initially expected, both the photophysical and fatigue resistance studies demonstrate that the photochromic behaviors of grafted dibenzothienylethenes are much less affected by the polar environment of the cellulose matrix than merocyanine switches. ${ }^{20,43}$ The absence of charges in both the open- and closed forms of dibenzothienylethenes most probably prevents any negative interaction with cellulose that could produce unwanted irreversible photochromism behavior.

(a)

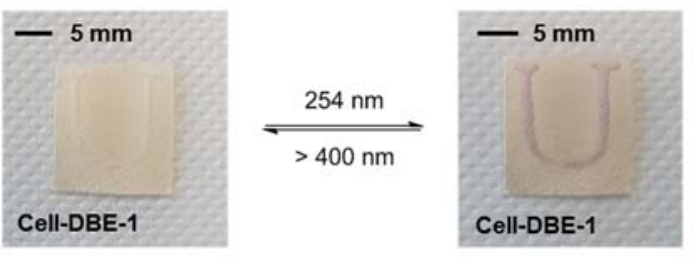

(b)

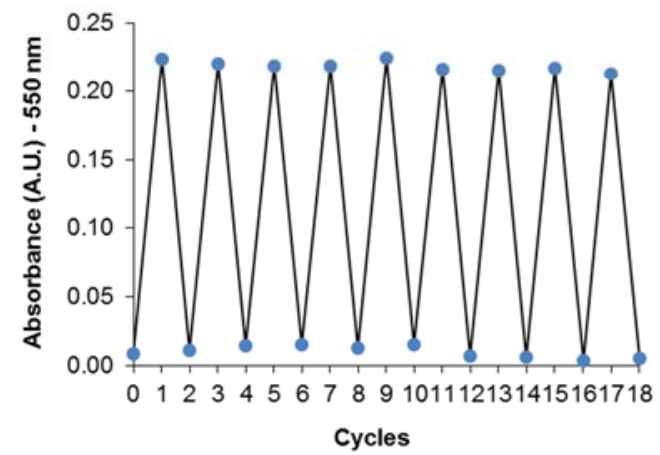

(c)

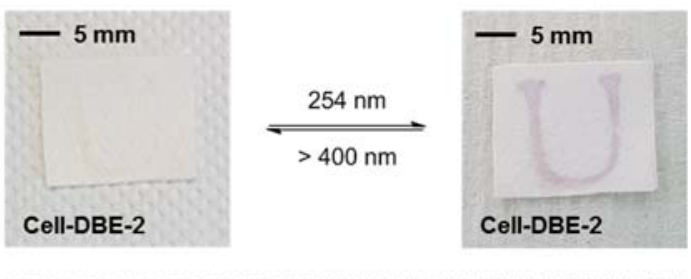

(d)

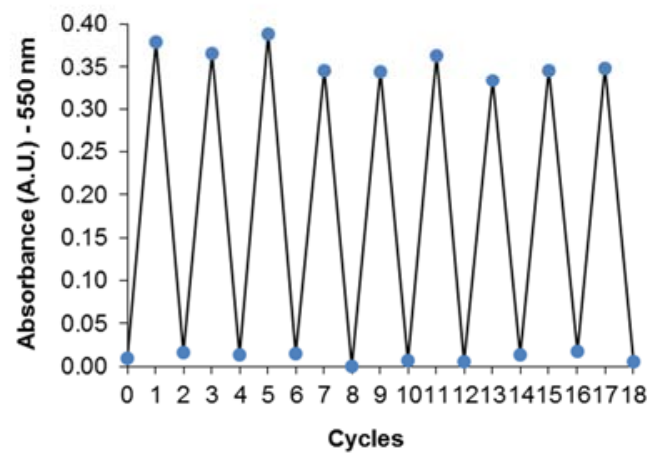


FiguRE 6. Photochromic behavior of patterned papers Cell-BDE-1 (a) and Cell-DBE-2 (c). Variation of absorbance intensity of Cell-BDE-1 (b) and Cell-DBE-2 (d) under UV (254 nm) and daylight cycles.

In order to compare the robustness of our covalent printing strategy with a simple adsorption process, we prepared the photochromic paper Cell-DBE-A which consists of the photochromic compound $\mathbf{8}$ adsorbed onto pristine cellulose paper (Figure 7). The high instability of $\mathbf{9 ( 0 )}$ and $\mathbf{1 0 ( 0 )}$ under the dry state precludes any adsorption test with these photochromic compounds on cellulose. While the photochromic behavior of $\mathbf{8}$ is visually preserved upon adsorption, a single washing of Cell-DBE-A in $\mathrm{CH}_{2} \mathrm{Cl}_{2}$ completely washedoff the circular pattern, validating the better robustness of our covalent printing with respect to adsorption processes. The same washing process carried out on Cell-DBE-2 (Figure 7d-f) does not affect the pattern, confirming that a covalent printing is much more robust than a simple adsorption.

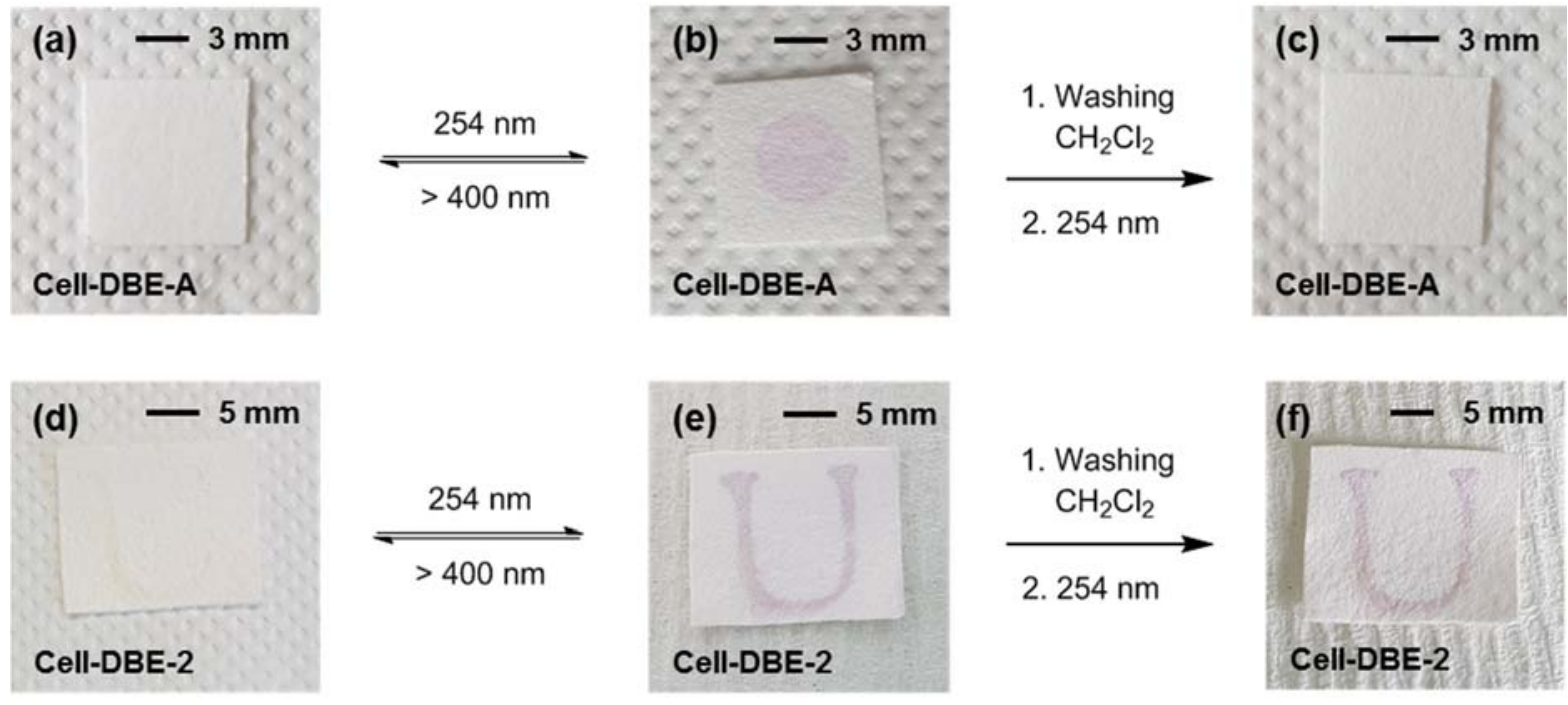

FIGURE 7. Photochromic behavior of patterned papers Cell-BDE-A (a) under visible light, (b) after irradiation at $254 \mathrm{~nm}$ for $1 \mathrm{~min}$, (c) after a single washing in $\mathrm{CH}_{2} \mathrm{Cl}_{2}$ followed by an irradiation at $254 \mathrm{~nm}$ for $1 \mathrm{~min}$ and Cell-BDE-2 (d) under visible light, (e) after irradiation at $254 \mathrm{~nm}$ for $1 \mathrm{~min}$, (f) after a single washing in $\mathrm{CH}_{2} \mathrm{Cl}_{2}$ followed by an irradiation at $254 \mathrm{~nm}$ for $1 \mathrm{~min}$. 
We have developed the first covalent patterning of cellulose paper with photochromic compounds. The strategy stands on the spatially-controlled light-mediated thiol-X ligation of dibenzothienylethenes (DBE) as photochromic compounds. The photophysical and theoretical studies are consistent with a reversible photochromic behavior of a thermally-stable DBE, not significantly affected by the hydrogen bond network of the cellulose matrix, and demonstrates the high fatigue resistance of the photochromic material over 18 successive write-erase cycles without decrease of the absorbance intensity. The robust covalent patterns are insensitive to successive washings in sharp contrast with patterns created through a non-covalent physisorbed process. We trust that the creation of robust molecularly imprinted photochromic patterns on cellulose paper is a promising technology that will find applications as anticounterfeiting device in fiducial documents.

\section{a ASSOCIATED CONTENT}

The supporting Information is available free of charge on the ACS Publication website at DOI: 10.1021/acsapi.XXXX.

NMR spectra of compounds: 1, 3-bromo-2-methylbenzothiophene, 4, 9, 7, 8, 9(o), 10(o) and 11 (PDF)

\section{口 AUTHOR INFORMATION}

\section{Corresponding Author}

\section{*E-mail: fx.felpin@univ-nantes.fr}

\section{ORCID}

Erwan Le Grognec: 0000-0002-3351-7028

Denis Jacquemin: 0000-0002-4217-0708

Takashi Hirose: 0000-0002-5351-2101

Kenji Matsuda: 0000-0002-2420-4214

François-Xavier Felpin: 0000-0002-8851-246X

\section{Notes}

The authors declare no competing financial interest.

\section{口 ACKNOWLEDGEMENTS}


We gratefully acknowledge the University of Nantes, the "Centre National de la Recherche Scientifique" (CNRS) and the "Région des Pays de la Loire" for financial support. GB acknowledges the JSPS summer program for a grant. Denis Loquet (University of Nantes), and Christine Labrugère (PLACAMAT, Bordeaux) are gratefully acknowledged for elemental and XPS analyses, respectively. We are grateful to Florian Massuyeau (Institut des Matériaux Jean Rouxel, Nantes) for providing us with UV spectrometers. This work used the computational resources of the CCIPL installed in Nantes.

\section{口 REFERENCES}

(1) Yu, A.; Shang, J.; Cheng, F.; Paik, B. A.; Kaplan, J. M.; Andrade, R. B.; Ratner, D. M. Biofunctional Paper via the Covalent Modification of Cellulose. Langmuir 2012, 28, 11265 11273.

(2) Tischer, T.; Claus, T. K.; Bruns, M.; Trouillet, V.; Linkert, K.; Rodriguez-Emmenegger, C.; Goldmann, A. S.; Perrier, S.; Börner, H. G.; Barner-Kowollik, C. Spatially Controlled Photochemical Peptide and Polymer Conjugation on Biosurfaces. Biomacromolecules 2013, $14,4340-4350$.

(3) Tischer, T.; Rodriguez-Emmenegger, C.; Trouillet, V.; Welle, A.; Schueler, V.; Mueller, J.

O.; Goldmann, A. S.; Brynda, E.; Barner-Kowollik, C. Photo-Patterning of Non-Fouling Polymers and Biomolecules on Paper. Adv. Mater. 2014, 26, 4087-4092.

(4) Wang, F.; Li, W.; Wang, J.; Ren, J.; Qu, X. Detection of telomerase on upconversion nanoparticle modified cellulose paper. Chem. Commun. 2015, 51, 11630-11633.

(5) Nishikata, T.; Tsutsumi, H.; Gao, L.; Kojima, K.; Chikama, K.; Nagashima, H. Adhesive Catalyst Immobilization of Palladium Nanoparticles on Cotton and Filter Paper: Applications to Reusable Catalysts for Sequential Catalytic Reactions. Adv. Synth. Catal. 2014, 356, 951960.

(6) Zheng, G.; Kaefer, K.; Mourdikoudis, S.; Polavarapu, L.; Vaz, B.; Cartmell, S. E.; Bouleghlimat, A.; Buurma, N. J.; Yate, L.; de Lera, Á. R.; Liz-Marzán, L. M.; PastorizaSantos, I.; Pérez-Juste, J. Palladium Nanoparticle-Loaded Cellulose Paper: A Highly Efficient, Robust, and Recyclable Self-Assembled Composite Catalytic System. J. Phys.Chem. Lett. 2015, 6, 230-238.

(7) Koga, H.; Kitaoka, T.; Isogai, A. In situ modification of cellulose paper with amino groups for catalytic applications. J. Mater. Chem. 2011, 21, 9356-9361. 
(8) Koga, H.; Kitaoka, T.; Isogai, A. Chemically-Modified Cellulose Paper as a Microstructured Catalytic Reactor. Molecules 2015, 20, 1495-1508.

(9) Rull-Barrull, J.; d'Halluin, M.; Le Grognec, E.; Felpin, F.-X. Harnessing the Dual Properties of Thiol-Grafted Cellulose Paper for Click Reactions: A Powerful Reducing Agent and Adsorbent for Cu. Angew. Chem. Int. Ed. 2016, 55, 13549-13552.

(10) Xiao, W.; Luo, Y.; Zhang, X.; Huang, J. Highly sensitive colourimetric anion chemosensors fabricated by functional surface modification of natural cellulose substance. RSC Adv. 2013, 3, 5318-5323.

(11) Gomes, H. I. A. S.; Sales, M. G. F. Development of paper-based color test-strip for drug detection in aquatic environment: Application to oxytetracycline. Biosens. Bioelectron. 2015, $65,54-61$.

(12) Rull-Barrull, J.; d'Halluin, M.; Le Grognec, E.; Felpin, F.-X. Chemically-modified cellulose paper as smart sensor device for colorimetric and optical detection of hydrogen sulfate in water. Chem. Commun. 2016, 52, 2525-2528.

(13) Rull-Barrull, J.; d'Halluin, M.; Le Grognec, E.; Felpin, F.-X. A paper-based biomimetic device for the reduction of $\mathrm{Cu}$ (ii) to $\mathrm{Cu}$ (i) - application to the sensing of $\mathrm{Cu}$ (ii). Chem. Commun. 2016, 52, 6569-6572.

(14) Hokkanen, S.; Bhatnagar, A.; Sillanpää, M. A review on modification methods to cellulose-based adsorbents to improve adsorption capacity. Water Res. 2016, 91, 156-173.

(15) d'Halluin, M.; Rull-Barrull, J.; Bretel, G.; Labrugère, C.; Le Grognec, E.; Felpin, F.-X. Chemically Modified Cellulose Filter Paper for Heavy Metal Remediation in Water. ACS Sustainable Chem. Eng. 2017, 5, 1965-1973.

(16) Nongbe, M. C.; Bretel, G.; Ekou, T.; Ekou, L.; Yao, B. K.; Le Grognec, E.; Felpin, F.-X. Cellulose paper grafted with polyamines as powerful adsorbent for heavy metals. Cellulose 2018, 25, 4043-4055.

(17) Sheng, L.; Li, M.; Zhu, S.; Li, H.; Xi, G.; Li, Y.-G.; Wang, Y.; Li, Q.; Liang, S.; Zhong, K.; Zhang, S. X.-A. Hydrochromic molecular switches for water-jet rewritable paper. Nat. Commun. 2014, 5, 3044-3051.

(18) Sun, B.; He, Z.; Hou, Q.; Liu, Z.; Cha, R.; Ni, Y. Interaction of a spirooxazine dye with latex and its photochromic efficiency on cellulosic paper. Carbohydr. Polym. 2013, 95, 598605.

(19) Tian, W.; Tian, J. Synergy of Different Fluorescent Enhancement Effects on Spiropyran Appended onto Cellulose. Langmuir 2014, 30, 3223-3227. 
(20) Tian, W.; Xue, Y.; Tian, J.; Gong, P.; Dai, J.; Wang, X.; Zhu, Z. Colorimetric and fluorometric dual-mode detection of aniline pollutants based on spiropyran derivatives. $R S C$ $A d v$. 2016, 6, 83312-83320.

(21) Tian, X.; Wang, B.; Li, J.; Zeng, J.; Chen, K. Surface Grafting of Paper with Photochromic Spiropyran Ether Methacrylate. BioResources 2016, 11, 8627-8637.

(22) Abdollahi, A.; Rad, J. K.; Mahdavian, A. R. Stimuli-responsive cellulose modified by epoxy-functionalized polymer nanoparticles with photochromic and solvatochromic properties. Carbohydr. Polym. 2016, 150, 131-138.

(23) Keyvan Rad, J.; Mahdavian, A. R. Preparation of Fast Photoresponsive Cellulose and Kinetic Study of Photoisomerization. J. Phys. Chem. C 2016, 120, 9985-9991.

(24) Li, W.; Trosien, S.; Schenderlein, H.; Graf, M.; Biesalski, M. Preparation of photochromic paper, using fibre-attached spiropyran polymer networks. RSC $A d v$. 2016, 6, 109514-109518.

(25) Abdollahi, A.; Mouraki, A.; Sharifian, M. H.; Mahdavian, A. R. Photochromic properties of stimuli-responsive cellulosic papers modified by spiropyran-acrylic copolymer in reusable pH-sensors. Carbohydr. Polym. 2018, 200, 583-594.

(26) Sun, B.; Hou, Q.; He, Z.; Liu, Z.; Ni, Y. Cellulose nanocrystals (CNC) as carriers for a spirooxazine dye and its effect on photochromic efficiency. Carbohydr. Polym. 2014, 111, 419-424.

(27) Irie, M. Diarylethenes for Memories and Switches. Chem. Rev. 2000, 100, 1685-1716.

(28) Irie, M.; Fukaminato, T.; Matsuda, K.; Kobatake, S. Photochromism of Diarylethene Molecules and Crystals: Memories, Switches, and Actuators. Chem. Rev. 2014, 114, 1217412277.

(29) Koga, H.; Nogi, M.; Isogai, A. Ionic Liquid Mediated Dispersion and Support of Functional Molecules on Cellulose Fibers for Stimuli-Responsive Chromic Paper Devices. ACS Appl. Mater. Interfaces 2017, 9, 40914-40920.

(30) Finnell, J. Invisible Markings and Conservation Treatment: An Exploratory Study. Library \& Archival Security 2011, 24, 19-24.

(31) Rull-Barrull, J.; d'Halluin, M.; Le Grognec, E.; Felpin, F.-X. Photoresponsive cellulose paper as a molecular printboard for covalent printing. J. Mat. Chem. C 2017, 5, 5154-5162.

(32) Bretel, G.; Rull-Barrull, J.; Nongbe, M. C.; Terrier, J.-P.; Le Grognec, E.; Felpin, F.-X. Hydrophobic Covalent Patterns on Cellulose Paper through Photothiol-X Ligations. ACS Omega 2018, 3, 9155-9159. 
(33) Hofsäß, R.; Rombach, D.; Wagenknecht, H.-A. Thieme Chemistry Journal Awardees Where are They Now?The Influence of Electron-Withdrawing Groups at the 2- and 2'Positions of Dibenzothienylethenes on Molecular Switching. Synlett 2017, 28, 1422-1426.

(34) Liang, F.; Lu, M.; Birch, M. E.; Keener, T. C.; Liu, Z. Determination of polycyclic aromatic sulfur heterocycles in diesel particulate matter and diesel fuel by gas chromatography with atomic emission detection. J. Chromatogr. A 2006, 1114, 145-153.

(35) Mosquera, Á.; Férnandez, M. I.; Canle Lopez, M.; Pérez Sestelo, J.; Sarandeses, L. A. Nonsymmetrical 3,4-Dithienylmaleimides by Cross-Coupling Reactions with Indium Organometallics: Synthesis and Photochemical Studies. Chem. Eur. J. 2014, 20, 1452414530.

(36) Berberich, M.; Würthner, F. Tuning the Redox Properties of Photochromic Diarylethenes by Introducing Electron-Withdrawing Substituents. Asian J. Org. Chem. 2013, 2, 250-256.

(37) Frisch, M. J., Gaussian 16, A.0.3. Wallingford, CT, 2016.

(38) Adamo, C.; Barone, V. Toward reliable density functional methods without adjustable parameters: The PBE0 model. J. Chem. Phys. 1999, 110, 6158-6170.

(39) Grimme, S.; Ehrlich, S.; Goerigk, L. Effect of the Damping Function in Dispersion Corrected Density Functional Theory. J. Comput. Chem. 2011, 32, 1456-1465.

(40) Tomasi, J.; Mennucci, B.; Cammi, R. Quantum Mechanical Continuum Solvation Models. Chem. Rev. 2005, 105, 2999-3094.

(41) Mamiya, J.-i.; Kuriyama, A.; Yokota, N.; Yamada, M.; Ikeda, T. Photomobile Polymer Materials: Photoresponsive Behavior of Cross-Linked Liquid-Crystalline Polymers with Mesomorphic Diarylethenes. Chem. Eur. J. 2015, 21, 3174-3177.

(42) Barrez, E.; Laurent, G.; Pavageau, C.; Sliwa, M.; Métivier, R. Comparative photophysical investigation of doubly-emissive photochromic-fluorescent diarylethenes. Phys. Chem. Chem. Phys. 2018, 20, 2470-2479.

(43) Dübner, M.; Spencer, N. D.; Padeste, C. Light-Responsive Polymer Surfaces via Postpolymerization Modification of Grafted Polymer-Brush Structures. Langmuir 2014, 30, 14971-14981. 